\title{
ІЛЮЗІЯ ДУХОВНОСТІ В СВІТІ ІНФОРМАЦІЙНОї ЗАВЕРШЕНОСТI
}

\begin{abstract}
A.B. Зуєв
Докорінні зміни світовлаштування та світогляду, що відбулися за останні два-три десятиліття, $є$ незаперечними і такими, що вплинули на життя кожного мешканця планети Земля (чому цивілізація і перетворилася на глобальну). Людина визнає, що змінилося все навколоречі, серед яких ми знаходимося, способи виробництва і споживання цих речей, відносини між людьми і соціальний інструментарій, інтелектуальна та естетична, побутова та інформаційна сфера. Єдине, чого не хоче визнавати людина, це те, що в потоці світозміни їй самій, істоті, що назвала себе вершиною світобудови, доводиться втрачати власні фундаментальні особливості, що визначали її велич та відчуття гордовитої самовпевненості.

Ми продовжуємо проголошувати свободу, справедливість, істину, красу, творчість духовним базисом нашого існування; продовжуємо використовувати ці слова, зіставляти з них самозаспокійливі теоретичні та ідеологічні конструкції, не прагнучи вже осягнути їх значення i жити відповідно до нього. Світ інформації надав нам дуже зручний інструмент: говорити будь-що про будь-що, адже інформація, будучи лише знаково-системною будовою, ніколи не мала сутнісної єдності з категорією істини. Тепер людина, перебуваючи в світі комфортної самозаспокоєності, легко може створювати собі імідж духовно сильного (насправді, маніпулятивно активного), творчого (мовою інформаційного світу - креативного) володаря власного життя.

Завданням даного дослідження $\epsilon$ визначення явища інформаційної замкнутості, завершеності як одної з головних характеристик знаковоінформаційної цивілізації, а також ілюстрація принципової неможли-
\end{abstract}

Актуальні проблеми духовності

(Відп. ред.: Я.В. Шрамко)

Кривий Ріг (2007), 29-38 
вості перенесення в світ інформації зі світу знання і творчості таких понять, як духовність, особистість, свобода тощо. Ілюзорна наявність подібних феноменів виключно у формі знакових утворень, звичайно, необхідна людині для самозаспокоєння та психічного комфорту, але ж, на нашу думку, теорія, особливо світоглядна, повинна ставити перед собою не завдання саморелаксації, а намагатися якомога чіткіше і відвертіше змалювати дійсну картину людського існування.

Теоретичною основою і джерелом понятійної різноманітності даного дослідження $є$ три філософські традиції, що склалися протягом двадцятого століття. Першою такою традицією стала, звичайно, екзистенціальна філософія, яка, в будь-якому своєму прояві, обов'язково задавалася питаннями про духовну складову людського буття. В твоpax М. Хайдеггера, К. Ясперса, Ж.-П. Сартра, Х. Ортеги-і-Гасета та інших постійно і настійливо звучить мотив можливості втрати людиною своєї духовної, особистісної сили, сили до життя, сили спротиву споживацькому стилю існування.

Екзистенціалізм чітко зазначав: людина $є$ істотою духовною; відібравши у неї цю особливість, ми знищуємо ï̈, перетворюючи на річ. Водночас, вже в середині XX століття в даній традиції виникають сумніви в тому, що в масовому суспільстві споживання можливе існування духовності як такої, а не її приємної імітації. Про таку масову «духовність» К. Ясперс пише: «Виникає сумнів в тому, що існує духовний рух, який діє так, щоб усі брали в ньому участь; можливо, ця доступність всім була б лише інерцією руху, який вже зупинився, який, зафіксувавшись в об'єктивності, здатен слугувати лише для розваги» [7, с. 394]. З'являється теоретична традиція чіткого розмежування поняття духовності як джерела людської творчості та духовності як ілюзорного інструменту розваги та самозаспокоєння.

Постмодерністська рефлексія (Ж. Дельоз, М. Фуко, Ж. Дерріда та ін.), зосередившись в 60-80-х роках минулого століття на знаково-текстовій природі сучасного світобачення, деонтологізувавши картину світу, перетворила будь-який вид людської активності на інтерпретаційні техніки. Зрештою, техніки знакових маніпуляцій стають основою інформаційної цивілізації, що народжується саме в цей період. Саме постмодернізм стає філософською основою формування знаковоінформаційного світу, в якому ми сьогодні живемо, і як, з нашої точки зору, найвідвертіший теоретичний базис сучасного світогляду, в якому не будуються величні ілюзії людської духовності, $є$ плідним джерелом теоретичної побудови картини світу, що складається з безлічі інформаційних уривків. 
Зрештою, третя філософська традиція, взята нами за основу дослідження, є другим етапом постмодерністських пошуків, який можна назвати постпостмодернізмом. Саме в концептах масовості сучасного цивілізаційного поля (Ж. Бодрійяр, Ф. Джеймісон, Ю. Осіпов) остаточно формується бачення безсуб'єктності, безособистісності, творчої аморфності та буттєвої безглуздості людської наявності в інформаційному середовищі. Сфера людського перебування перетворюється на сферу інформаційної імпульсності, а будь-який рух людини полягає в отриманні та передачі інформаційного імпульсу. Людина, будучи масою, вже не є ні суб'єктом, ні об'єктом будь-якої активності. «Маса парадоксальна - вона не є ні суб'єктом (суб'єктом-групою), ні об'єктом. Коли її намагаються перетворити на суб'єкт, виявляється, що вона не в змозі бути носієм автономної свідомості. Коли ж, навпаки, її прагнуть зробити об'єктом, тобто розглядають як матеріал, що підлягає обробці, і ставлять за мету проаналізувати об'єктивні закони, яким вона нібито підпорядковується, стає ясно, що ні обробці, ні розумінню в термінах елементів, відношень, структур та сукупностей вона не піддається. Будь-який вплив на масу, потрапляючи в поле її тяжіння, починає рухатися по колу: він проходить стадії поглинання, відхилення і нового поглинання. Чим такий вплив закінчиться, з абсолютною точністю передбачити неможливо, але найвірогідніше, що безперервний коловорот забере в нього всі сили і він згасне, повністю перекресливши усі плани тих, хто його чинив» [2, с. 37-38]. Отже, третя теоретична основа нашого дослідження прямо проголошує відсутність і неможливість будьякої творчої активності в світі інформаційної масовості.

Визначимо тепер три ключові понятійні позиції нашого дослідження: духовність, інформаційна розірваність, яка є основною характеристикою сучасної цивілізації, та інформаційна завершеність. Саме співвідношення між цими поняттями дасть нам змогу висвітлити проблематику сучасного ставлення людини до власної сутності та світоглядних орієнтирів.

Духовністю ми традиційно будемо вважати ту внутрішню силу людини, що дає їй змогу відчути себе і самоствердитись як особистості, тобто усвідомлювати, що саме на основі власних переконань про красу та справедливість, істину та абсолютність життя можна творити таку цілісність себе, яка буде важливою для іншої людини, що сама займається самотворчістю. Прагнення до створення цілісної картини світу та до актуалізації власного буття заради «іншого» і є головним проявом духовної енергії. Опис такого відчуття цілісності світу та самоважливості знаходимо у А. Чехова: «И несчастный, надорвавшийся, убивший 
себя „неврастеник“, как назвал его доктор, и старик мужик, который всю свою жизнь каждый день ходит от человека к человеку, - это случайности, отрывки жизни для того, кто и свое существование считает случайным, и это части одного организма, чудесного и разумного, для того, кто и свою жизнь считает частью этого общего и понимает это» [6, с.318]. Для того, щоб така цілісність не просто відчувалася, а була явленою, невід'ємною частиною людського буття, і є необхідним звільнення духовної енергії, напруга, що дозволить втаємниченість цілісності зробити особистісною очевидністю. «Буття не є. Буття має місце як вихід присутності із втаємниченості» [5, с. 394]. Духовність, таким чином, завжди була необхідною умовою людської буттєвості, адже саме вона уособлювала ту енергію, на основі якої людина самостверджувала власну наявність.

Основою ж інформаційного світу є не енергетична наповненість, що постійно являла нове через творчі пориви духовної істоти, а циркуляція інформаційних середовищ та уривків, які є сутнісно не пов'язаними між собою. Інформаційна розірваність сучасної цивілізації полягає в тому, що ця цивілізація існує виключно на основі відсутності онтологічної схеми. Інформація не повинна відповідати певним вимогам людської буттєвості, вона не повинна задовольняти одвічні потяги людини до істини, краси і справедливості. Єдиним ㄲï завданням є циркуляція та продукування безлічі комфортних уривків для задоволення окремих людських потреб. Хочеш зранку бути релігійним - подивись християнський канал по телебаченню, прочитай церковний календар в Інтернеті, помолися в одній з безлічі комерційних установ, що називаються церквами; вдень тобі необхідно заробити грошей-в тебе $\epsilon$ безліч спекулятивних можливостей забезпечити свій матеріальний комфорт; ввечері хочеться розслабитися - порнографічність масової культури надасть тобі безліч можливостей декілька годин насолоджуватися життям. Ми маємо безліч схем переміщення між інформаційними середовищами, які не пов'язані між собою ні світоглядно, ні змістовно, ні технічно - вони є принципово розірваними, переміщуючись між якими ми легко забуваємо про попереднє місце знаходження.

Зрештою, інформаційна завершеність - це основний принцип існування будь-якого інформаційного сегмента. Цей принцип полягає в тому, що з самого початку дії інформаційного середовища всі можливі рухи та маніпуляції, які в ньому відбуваються, задані наперед, запрограмовані згідно з певним алгоритмом, кодом, який визначає правила поведінки в даному середовищі. Це можуть бути як коди соціального характеру (професійні, релігійні, розважальні тощо), так і коди ство- 
ренні в рамках виключно автоматизованих систем. Причому за умов інформаційної цивілізації системи автоматизовані є домінантними, такими, що визначають природу соціальних взаємодій в межах певного знаково-інформаційного сегменту. Таким чином, потрапляючи в будьяке інформаційне середовище, людина наперед знає, чим завершиться iii в ньому перебування. Декілька прикладів:

- комп'ютерні ігри (на яких сьогодні виховуються діти) - починаючи грати в будь-яку комп'ютерну гру, я знаю чим моя дія закінчиться. Я виконаю всі задані наперед quest-и, переможу всіх монстрів, які вже потенційно переможені і отримаю винагороду, яка вже запрограмована;

- професійне середовище, в яке кожний з нас потрапляє, теж не містить нічого іншого, окрім алгоритму необхідної поведінки дотримуйся заданих правил і досягнеш кар'єрного успіху;

- мистецьке середовище - алгоритм взагалі дуже простий: створюєш необхідний імідж за будь-яким з безлічі рецептів, що циркулюють у відповідних сегментах, і насолоджуєшся результатом.

Таку завершеність ми знаходимо в будь-якій сфері інформаційної активності, а щоб бути сьогодні активним, в будь-якому разі необхідно потрапити у вихор інформаційної циркуляції. Отже, єдиною умовою успішної діяльності на сьогодні $є$ присутність в тому чи іншому інформаційному сегментові у вигляді знаково-символічного утворення. Потрапивши в таке середовище, людина вже не потребує докладання власної енергії задля розвитку і самовдосконалення, адже в інформаційному сегменті вже все завершено, в ньому необхідно просто перебувати і насолоджуватися таким перебуванням. Насолода ця полягає саме в тому, що ми забезпечуємо собі максимальний комфорт, фізичний і психічний, не докладаючи жодних творчих зусиль.

Поглянемо спочатку на когнітивну складову нашого сучасного існування. Чи прагнемо ми сьогодні до істини? Чи потребує її сучасна людина в світі, де на будь-яке своє запитання вона може знайти зручну для неї відповідь? Ми довго прагнули до плюралізму думок і свободи вибору, але набули зовсім інших можливостей. Плюралізм думки полягав, насамперед, в тому, що будь-яка проблема була спільною для тих, хто по-різному намагався її вирішити. Ми ж отримали інформаційну розірваність, де я як хочу, так і ставлю перед собою завдання, як хочу, 
так його і вирішую. Свобода ж вибору завжди передбачала онтологічне підгрунтя і енергетичність, творчу природу такого вибору. Тепер я обираю лише те, в яке інформаційне середовище мені зануритися. Перетворившись з особистостей і індивідуумів на дивідуумів, ми постійно ділимося, розриваємося на безліч знаків і символів, забуваючи, що колись єдине, що було для нас важливим, єдине, на що ми спрямовували свою духовну енергію, було знання істини про самих себе. В світі інформаційної розірваності ми замінили цю істину безліччю непов'язаних між собою тверджень, точок зору, психотехнік, приємних образів, між якими ми обираємо. Одним з таких приємних знаків, до речі, є слово «духовність», яка нам тепер приносить не напруження і дискомфорт, а лише насолоду від відчуття власної величі.

Перетворення ціннісних сутностей, що мали духовно-комунікативний характер, на знакові одиниці, символічні формули створило для людини зручний, комфортний ландшафт етичної розслабленості, адже тепер єдиною діяльністю з моральним навантаженням $є$ маніпуляція зі знаками та їх інтерпретація. «Совість», «Добро», «Зло», «Краса», «Істина», «Співчуття» тощо - стали знаковими одиницями, розташовуючи які в тій чи іншій інформаційній системі в необхідній для мене комбінації, я утворюю зручне і приємне для мене «морально-символічне» середовище. Будь-який мій вчинок вимірюється тією системою знаків, яку я сам обрав, занурившись в завершене, зпродуковане інфосередовище перебування.

Сьогодні для нас є нормальним той символічно-моральний стан, який свого часу М. Бердяєв змалював як патологію людської духовності: «Все моральне життя, що кристалізується в нравах, засноване на символіці, а не на реальному духовному перевтіленні людей. Мораль, грунтована на законності, потребує від людей виконання умовних символів, що не мають обов'язкового реального зв'язку з їх внутрішнім життям, з їх духовністю. Виконання обов'язку має символічний характер. В спілкуванні людей необхідно подавати один одному знаки, які можуть зовсім не відповідати реальностям. Так звані „добрі справи“ можуть носити знаковий символічний характер. Милосердя може бути символічним, а не реальним. Так зване лицемірство є крайньою формою символізму, з якого зникла будь-яка реальність. У світі об'єктивації немає відношення до живої, конкретної особистості, а є відношення до об'єктів. Але у відношеннях до об'єктів реальності є недосяжними, вони вислизають. Відношення до об'єктів завжди символічне» [1, с. 395].

Заклавши в «буттєві» (фактично деонтологізувавши своє існува- 
ння) основи нашої цивілізації системи знаково-інформаційного маніпулювання, ми створили ситуацію, де до будь-чого відбувається виключно символічне ставлення. Від економічної сфери, де символічні тренди та маніпуляції з фіктивними фінансовими «субстанціями» визначають основні тенденції розвитку, до моральної мотивації поведінки, яку можна обрати з багатьох запропонованих схем,- увесь наш сьогоднішній світ $є$ в основі своїй символічним, а отже безосновним, адже символи так легко змінювати, а маніпулювати ними так зручно!

Виникає питання: якщо світ людини перетворився на переміщення між замкнутими, сформованими, необмежено продукованими знаковими реальнстями та їх інтерпретаціями, чи не призведе це до абсолютної хаотизації людського існування? Ствердну відповідь ми дали б на це питання, використовуючи онтологічно та етично наповнені категорії світу, де панувало прагнення до знання та істини. В світі ж символічної інформаційності хаосу запобігає не прагнення до осмисленості буття, а просте кодування, шифрування окремих закритих реальностей. Так, щоб перебувати і функціонувати в тій чи іншій інформаційній сфері, необхідно просто потрапити в неї, для чого потрібно знати код, та виконувати необхідні функціональні обов'язки, для чого необхідно знати алгоритм даної системи.

Гасло сучасного комфортного існування: «Роби, що зафіксовано, і май все, що необхідно для комфорту!» Для прикладу: потрапити до певної професійно-знакової сфери можна застосувавши код - диплом про відповідну освіту, який зовсім не означає, що людина може створювати знання, але точно значить, що вона може з різним рівнем успішності маніпулювати інформацією в даній сфері, тобто ознайомлена з основними шифрами і алгоритмами. Далі - просто виконуй дії, які вже прописані і зафіксовані в інформаційній матриці даного середовища і насолоджуйся тим, що воно тобі дає.

Складається абсолютно нова «суспільна» матриця, в якій жодного значення не має енергія творчості, духовна напруга і невдоволення наявною ситуацією, натомість домінуючим фактором людського існування $є$ володіння кодовою інформацією. Саме таке кодування $є$ знаковим запобіжником, який не дозволяє людині усвідомити хаотичність власного існування, а створює ілюзію впорядкованості і зрозумілості. «Цифрова мова суспільств контролю заснована на шифрі, який допускає вас до інформації або відмовляє у доступі. Ми більше не маємо справи з парою „маса-індивідуум“. Індивідууми стають „дивідуумами“, а маси - семплами, ринками та банками даних» [3, с. 229]. Тепер, щоб займатися певною діяльністю, необхідно лише потрапити в пев- 
не знакове середовище, не докладаючи жодних особистісних зусиль головне знати шифр.

Ще одним виміром сучасних переміщень людини між замкнутими інфосферами є гіпервіртуалізація світу. Гіпервіртуалізація означає фактичне знищення поняття віртуальності, витіснення його 3 нашого життя. Розуміння віртуальності як реальності, що породжується людською свідомістю і є закритою на основі того, що будь-яке в ньому перебування завершується поверненням до реальності константної, буттєвої, постійної, втілювало прагнення людини до створення чогось нового, іншого, до фантазії і мрії з постійним усвідомленням того, що основна реальність $є$ відкритою, такою, де панує необхідність і свобода вибору.

В світі інформаційного функціонування ми називаємо віртуальними реальності, які жодним чином не пов'язані з будь-якою константністю. Сьогодні ми переміщуємося між інформаційними сегментами, не маючи можливість повернутися до реальності буттєвої, де ми могли б проявити свій дар творчості. «Навкруги тепер гола віртуальність, не та віртуальність, яка поєднана з реальністю, а віртуальність сама по собі, від себе, з себе, та сама віртуальність, яка заміщує собою реальність, їі поглинає і собою являє, але при цьому і робить. Тепер не віртуальність від реальності, а реальність від віртуальності, що, погодимось, зовсім не одне й те саме. I хіба це не дійсно новий, не просто небувалий раніше, а зовсім інший світ, який тут, на Землі, не де-небудь, але який вже не несе в собі нічого від джерел, від історії, від істини, якому все це байдуже, який від всього цього у відриві, як у відриві він від Природи і Бога, взагалі від сущого» [4, с. 77]. Розірваність людського існування в світі інформаційних сегментів стає домінуючим мотивом нашого існування.

Зрештою, в світі, де людину визначала здатність до звільнення духовної енергії, ключовим моментом людського існування був час. Caме в середовищі минулого, теперішнього і майбутнього формувалася людська особистість. Згадки, туга, відповідальність за минуле, свобода вибору теперішнього, сподівання, мрія і страх перед майбутнім визначали силу тієї духовної енергії, яка змушувала людину ставати тією єдністю і цільністю, яку ми називали особистістю. Тепер, переміщаючись між інфосферами, ми втрачаємо відчуття часу, адже різні знаково-інформаційні системи не мають між собою нічого спільного, а особливо - єдиного онтологічного підгрунтя.

По-перше, різні інформаційні сфери мають різну темпоральність, що не дозволяє сприймати їх в одній системі «минулого-теперішнього- 
майбутнього». По-друге, і це є найголовнішим, кожна з таких сфер, будучи визначеними наперед, замкнутими і завершеними, залучаючи людину до своєї внутрішньої функціональності, одразу і дуже наглядно демонструє, що буде відбуватися як на початку, так і наприкінці перебування в цій сфері, яким буде результат такого перебування. Функція людини як знаку може мінятися, сутність її як особистості для інфосистеми абсолютно не важлива. Тут не потрібно докладати зусиль для самовдосконалення і самореалізації, адже вони вже відбулися, завершилися, коли людина застосувавши володіння кодом потрапила в дане середовище - на цьому духовний час зупиняється. Людина перестала жити в світі історії (історія перетворилася на кумедні символи), тоді як раніше ми не могли себе уявити поза нею: «Те, що належить показати в образі теперішнього, ніколи не буває цим теперішнім повністю. Кожен живе у світі ще неусвідомлених можливостей. Існує нібито певний закон: те, що ми знаємо, вже не є шляхом субстанційної історії» [7, с. 395]. Людина в світі знання і духовного прагнення до істини була відкритою історичній субстанційності. Втративши таку відкритість, сховавшись серед комфорту розірваного інформаційного світу, ми продовжуємо тішитися духовністю як знаком, приємним і необхідним для самозаспокоєння.

Отже, людина, потрапивши в абсолютно новий світ, перемістившись із середовища духовних прагнень та знання у середовище символів і знаково-інформаційних систем, продовжує використовувати категорії і поняття, які були для неї сутнісно визначальними і аксіологічно фундаментальними, у вигляді знаків, символів, які тепер використовуються виключно задля самозаспокоєння та розваги. Нам приємно називати самих себе творчими істотами, не зважаючи на те, що сьогодні «творчість» полягає виключно в маніпуляції знаками і їх системами; нам приємно думати, що духовність $є$ нашою внутрішньою сутністю, яка відрізняє нас від всього іншого, водночас, ми комфортно розташовуємося в завершених інфосферах, переймаючись лише власною функціональністю.

Принципово завершені, закодовані, алгоритмізовані інформаційні системи, які є сьогодні основою нашої цивілізаційності, жодним чином не передбачають творчої активності людини в межах внутрішньої функціональності. Таким чином, чи можемо ми сьогодні казати про духовні основи особистості і суспільства, якщо домінантним принципом сучасного світу є інформаційна циркуляція? Принциповим питанням для сучасної філософії є, на нашу думку, аналіз того, яким чином і з якими мотиваційними чинниками сучасна людина застосовує та- 
кі категорії, як духовність, творчість, особистість, свобода тощо. Чи можемо ми в рамках знаково-інформаційної цивілізації дійсно надавати значення цим поняттям, чи ми лише використовуємо їх як знаки, необхідні для зручного облаштування того чи іншого інформаційного сегменту. Принаймні, одна з ознак сучасної цивілізації-замкнутість, завершеність її формуючих, інформаційних сегментів, - досить чітко визначає, що символічний образ духовної енергії ми сьогодні використовуємо як ілюзію власної величі і творчої наснаги, виключно заради власного самозаспокоєння і самолюбування.

\section{1 Бібліографія}

[1] Бердлев Н.А. Дух и реальность. Основы богочеловеческой духовности // Бердяев Н.А. Философия свободного духа.- М.: Республика, 1994. - С. 364-462.

[2] Бодрийар Ж. В тени молчаливого большинства. - Екатеринбург: Изд. Уральского университета, 2000.

[3] Делёз Ж. Переговоры.-СПб.: Наука, 2004.

[4] Осипов Ю.М. Неуловимая современность // Осипов Ю.М. Эпоха постмодерна. В трех частях. - М.: ТЕИС, 2004.- С.62-78.

[5] Хайдеггер M. Время и бытие.-М.: Республика, 1993.

[6] Чехов А.П. По делам службы // Чехов А.П. Собрание сочинений в двенадцати томах. Том 9.- М.: Издательство Правда, 1985. C. 306-320.

[7] Ясперс К. Духовная ситуация времени // Ясперс К. Смысл и назначение истории. - М.: Республика, 1994. - С. 288-418. 